\title{
"Estaba en el primero cartapacio pintada muy al natural la batalla de don Quijote con el vizcaíno"; movimiento y ambigüedad en un pasaje ecfrástico en El ingenioso hidalgo don Quijote de la Mancha
}

\section{Gerardo ALTAMIRANO Universidad Nacional Autónoma de México}

Uno de los varios pasajes en los que Cervantes utiliza la técnica de la écfrasis en su obra El ingenioso hidalgo don Quijote de la Mancha, es en la descripción de una imagen que logra unir la primera y segunda parte de la publicación de 1610 . Se trata de una imagen plasmada en un cartapacio en la que se retrata la célebre batalla entre en caballero manchego y el vizcaíno. En este escrito intento proponer este pasaje como uno de naturaleza ecfrástica y explico, además, las características peculiares que posee, como es el caso de la enárgeia y los juegos de direccionamiento de miradas que propone su autor.

PALABRAS CLAVE: écfrasis, enárgeia, don Quijote, vizacaíno, cartapacio.

One of the several passages in which Cervantes, in El ingenioso hidalgo don Quijote de la Mancha, uses the ekphrasis as a rhetorical technique is that one in which the author describes "el primero cartapacio"; it means, a kind of antique folder on which the battle between Don Quijote and the Vizcaíno was supposedly drawn. In this paper, I try to propose this passage as one of ekphrastic nature, and, besides, I do explain some specific characteristics that it contains, such as the use of enargeia and the plays or roles of looking addressing that are proposed by the author.

KEY WORDS: ekphrasis, enargeia, Don Quijote, Vizcaíno, cartapacio.

Gerardo Altamirano Meza A Margit Frenk

Yo apostaré — dijo Sancho- que antes de mucho tiempo no ha de haber bodegón, venta ni mesón o tienda de barbero donde no ande pintada la historia de nuestras hazañas; pero querría yo que la pintasen manos de otro mejor pintor que el que ha pintado a éstas.

Miguel de Cervantes, El ingenioso hidalgo don Quijote de la Mancha, II, cap. LXXI.

\section{Introducción}

La segunda parte del Quijote de 1605 inicia con uno de los pasajes más interesantes y polémicos de la obra, el episodio del "Hallazgo del manuscrito". Aquí, Cervantes 
se valió de algunos recursos literarios que si bien ya contaban con toda una tradición para esa época, el famoso escritor logró reformular y unir de manera magistral. Entre estos recursos, no solamente se halla el motivo del manuscrito encontrado o la traducción de un texto proveniente de alguna lengua exótica - motivos que, sin duda, el escritor hispano obtuvo de los diversos textos caballerescos de los que se nutrió-, sino también aquella técnica que, según los rétores de los siglos III y IV, hacía poner "ante los ojos" cualquier cosa que se describiera; me refiero a la écfrasis o descripción poética de un objeto artístico, que en la obra cervantina aparece en más de una ocasión y que, en el pasaje aludido, se sitúa cuando se habla del cartapacio en el que se retrata, supuestamente de manera fiel, la batalla del legendario caballero manchego contra el vizcaíno. ${ }^{1}$

El objetivo del presente escrito es responder a las siguientes preguntas: ¿cómo emplea Cervantes la técnica de la écfrasis aplicada a su magistral obra? ¿Realmente reproduce de manera fiel la realidad intratextual que la imagen representa? ¿Qué implicaciones y funciones tiene esta descripción artística? ¿Qué tradición, imitación, parodia o juego hay detrás de todo esto?

\section{1. Écfrasis; conceptualización teórica y algunas noticias del recurso literario en la Antigüedad y en la Edad Media}

Quien desdeña la pintura, delinque contra la verdad, delinque también contra toda esa sabiduría que debemos a los poetas, ya que poetas y pintores contribuyen por igual a nuestro conocimiento de las gestas y el aspecto de los héroes.

Filóstrato, Descripciones de cuadros, I.

En sus Progymnásmata o ejercicios retóricos, los rétores helenísticos del siglo IV definieron la écfrasis (del gr. $̌ ̋ \varphi \rho \alpha \sigma l \xi)$ como el acto de describir algo y lograr que lo descrito se mostrara ante los ojos de quien escuchara. Aftonio de Antioquía señaló: "Una descripción ( $\check{\kappa} \kappa \rho \alpha \sigma l \xi)$ es una composición que expone en detalle y presenta ante los ojos de manera manifiesta el objeto mostrado. Se han de describir personas y hechos, circunstancias y lugares, animales y, además, árboles y personajes, como lo hace

\footnotetext{
${ }^{1}$ Otro de los capítulos en los que Cervantes utiliza esta técnica retórica es el capítulo LXXI, del cual he extraído el epígrafe que inaugura el presente estudio. En un breve resumen, en ese capítulo Sáncho y Don Quijote se alojan en un mesón, en cuya planta baja hay ciertas pinturas en las que se relatan hechos relacionados con la desgracia de Troya: el rapto de Helena y el suicidio de Dido. Resulta interesante que estas obras de arte sean de malísima calidad, lo cual se explica por la parodia que la obra representa. Así, refiriéndose a las pinturas ya mencionadas Don Quijote le responde a su compañero: “Tienes razón, Sancho — dijo don Quijote-, porque este pintor es como Orbaneja, un pintor que estaba en Úbeda que, cuando le preguntaban qué pintaba, respondía: 'Lo que saliere'; y si por ventura pintaba un gallo, escribía debajo: 'Este es gallo', porque no pensasen que era zorra" (II, LXXI).
} 
Homero [...]. De las descripciones unas son simples y otras compuestas" (Ejercicios, 253-254).

De aquí se entiende que, en la Antigüedad tardía, cualquier descripción era considerada ecfrástica y así se conservó el concepto hasta la Edad Media y entrada la Modernidad. En este sentido, Curtius nos recuerda que, en la época medieval, la écfrasis estuvo estrechamente relacionada con el discurso panegírico, que describía personas, lugares, edificios, etcétera (1995: 108). ${ }^{2}$

Sin embargo, el concepto moderno que tenemos de esta técnica es únicamente el de una descripción literaria de un objeto plástico y artístico - pensemos en la descripción de una escultura, una pintura o un grabado-; hecho que debemos a Leo Spitzer, pues fue él quien, en el siglo Xx, delimitó el uso del término al definir la écfrasis como "the poetic description of a pictorial or sculptural work of art" ("Theode...", 207); una afirmación que logró desencadenar otras conceptualizaciones modernas, así como otras apreciaciones estéticas, que sentaron las bases para que algunos teóricos dieran también su punto de vista; entre ellos, James Heffernan, quien, en Museum of words, define la écfrasis como "the verbal representation of a visual representation" (3).

Partamos de la idea de la écfrasis como la descripción literaria de un objeto artístico, y digamos que, desde la Antigüedad, la literatura ha contado con ejemplos numerosos de esta técnica. Entre ellos, no podemos omitir, por una parte, las descripciones ecfrásticas que se insertan en ciertas obras épicas y que, con palabras, dibujan algunos armamentos heroicos o bien objetos que se relacionan con la vida tanto de los héroes clásicos como de los caballeros andantes. La écfrasis más célebre, en este sentido, es la que hace Homero en el canto XVIII de la Ilíada, con respecto al escudo de Aquiles, y en la cual el autor logra re-presentar una imago mundi, pues Vulcano "hizo figurar en él toda la tierra, el cielo, y el mar, el infatigable sol y la luna llena, así como todos los astros que coronan el firmamento: las Pléyades, las Híades y el poderío de Orión” (vv. 482-486).

Por otra parte, la Edad Media también practicó esta técnica con relativa frecuencia. ${ }^{3}$ En este sentido, tan sólo hay que recordar la écfrasis de la tienda de Alejandro, en el Libro de Alexandre. Y es que, en el último de los cuatro paños que componen la tienda, el autor del texto nos dice que el artista - Apeles de Cos — ha plasmado con colores toda la biografía del emperador macedonio. De esta manera:

\footnotetext{
${ }^{2}$ En su artículo "La écfrasis de los ejércitos o los límites de la enárgeía", Lozano-Renieblas hace un resumen interesante de los distintos tipos de écfrasis de los que podían hablar los rétores de los siglos III y IV. De esta manera, recuerda: "los autores de los Progymnásmata repiten cuatro modalidades: la descripción de personas (prosoma), de circunstancias o hechos (prágmata), de lugares (tópoi) y de periodos de tiempo (crónoi). Elio Teón añade, además, la descripción de costumbres; Aftonio, la de animales y plantas. Sólo en el siglo $\mathrm{V}$, Nicolao incluye la écfrasis de festivales y obras de arte" (30).

${ }^{3}$ En el caso del motivo del escudo historiado, además de tener una pervivencia virgiliana con el escudo de Eneas, que se describe en la Eneida, no está por demás recordar que entre los textos que dieron a conocer la materia de Troya, en la temprana Edad Media, se encuentra la Ilias Latina, opúsculo redactado hacia el siglo I d. C. y escrito en latín, en el que, si bien a modo de abreviatio, también se presenta la afamada descripción del escudo homérico.
} 
Escrivió el maestro en el cuarto fastial

las gestas del buen rey, súpolas bien pintar;

$[\ldots]$

Cómo passó a Asia a Dario buscar;

cómo Troya ovo en Frigia a fallar;

lafazienda de Tiro no la quiso lexar,

cómo sopo su onra el rëy bien vengar.

(cc. $2588 \mathrm{ab} ; 2590)$

Finalmente, los libros de caballerías — tan caros a Don Quijote — también utilizan el recurso ecfrástico con distintos fines. Campos García Rojas ha hablado, por ejemplo, del aprendizaje histórico e incluso del amor que tiene su origen en una obra artística — amor ex arte- ("Historia y amor...”). Así, el investigador recuerda que, en el Caballero del Febo, uno de los libros favoritos de Don Quijote, la princesa Claridiana se enamora del protagonista gracias a una pintura que observa en los muros de la cueva de la sabia Oligas. El texto fuente dice lo siguiente:

Assi, passaron adelante, y la dueña llevó a la princessa de una quadra en otra hasta que vinieron a dar en una grande y muy hermosa sala, en las paredes de la qual estavan pintadas las más hermosas donzellas que avía en el mundo, y las que en tiempos passados tuvieron fama de hermosas, entre las cuales vio la princessa su mesmo rostro [...]. Y saliendo de aquella sala, fueron a dar en otra, en que estavan pintados todos los caballeros famosos que avía avido en el mundo, [...] entre los quales vio el retrato de aquel Cavallero del Febo, que sobre todos los otros se parescía y manifestava, el qual tenía delante todo el castillo de Lindaraxa, y las grandes y espantosas batallas que allí avía avido [...]. Que como la real princessa pusiesse en él los ojos, y lo viesse así tan grande y bien hecho, y aquel su severíssimo rostro, que parecía más celestial que humano, junto con los grandes y espantosos hechos que tenía delante, súbitamente se sintió herida de su amor (III, 221-223).

No obstante, la literatura de la Edad Media no fue la última que, con tanto ahínco, empleó esta técnica, sino que también la producción literaria de la Modernidad se valió de la descripción de objetos artísticos para llegar a ciertos fines. ${ }^{4}$ Luego, es necesario hablar de la presencia ecfrástica en El ingenioso hildalgo don Quijote de la Mancha, cuyo capítulo IX de la segunda parte de 1605 contiene la descripción de aquel cartapacio donde se encontraba "pintada muy al natural la batalla de don Quijote con

\footnotetext{
${ }^{4}$ Para el estudio de la écfrasis como práctica literaria en los siglos XV, XVI y XVII resulta fundamental la consulta del siguiente texto: Ekphrasis in theAge of Cervantes. Comp. Frederick A. De Armas. Lewis-burg: Bucknell: University Press, 2005. No obstante, es deber resaltar que, entre los artículos reunidos aquí, no hay uno que se dedique a la écfrasis medieval, como si esta práctica hubiese sido tan sólo empleada en ciertas épocas históricas y literarias; no obstante, como se ha sugerido en este trabajo, constituye una tradición ininterrumpida.
} 
el vizcaíno" (I, 9, p. 87). Antes de hacer un análisis de esta obra re-presentada, contextualicemos el episodio.

\section{La écfrasis del "primero cartapacio", contexto y descripción}

Tras el célebre combate con los fieros y soberbios gigantes del capítulo VII de la primera parte, que no resultaron ser más que molinos de viento, Don Quijote queda muy lastimado e incluso humillado. Empero, sus quejas no son expresadas porque -él mismo dice - "no es dado en los caballeros andantes quejarse de herida alguna, aunque les salgan las tripas por ella" (I, VIII, 77).Por el contrario, el famoso manchego sigue en busca de aventuras que, frente al mundo y ante a su señora, lo llenen de honor, gloria y fama.

Cierto día, y de repente, él y Sancho ven venir sobre el camino a dos frailes de la orden de san Benito, a quienes el caballero cree malvados encantadores que han raptado a una supuesta princesa, quien, a su parecer, viene cautiva en un coche. De esta manera Don Quijote, acostumbrado a "enderezar tuertos y desfazer agravios", entabla una cruel y feroz lucha contra quienes cree raptores, de la cual sale vencedor, y los adversarios, fugitivos. Es entonces que el andante manchego se acerca al carro donde viene la dama, para identificarse ante ella y pedirle que, en pago del beneficio obtenido, regrese con su comitiva al Toboso, para dar a la señora Dulcinea noticas de su adorador.

Como recordará el lector, al escuchar semejante petición — desmesurada e irracional en todo momento-, un escudero que viene con la dama enfrenta a Don Quijote con "mala lengua castellana y peor vizcaína” (I, VIII, 80). Los insultos no esperan demasiado y la trifulca comienza. Cervantes hace, luego, toda una descripción de la batalla, la cual no deja de ser una parodia de los enfrentamientos relatados en los libros de caballerías, donde los héroes entablan luchas carniceras con sus fieros enemigos y las doncellas, implorantes, observan esto desde un punto alejado, tal vez una torre. En este caso, un coche. De esta manera: "El vizcaíno aguardaba a Don Quijote asimismo levantada la espada y aforrado con su almohada, todos los circunstantes estaban temerosos y colgados de lo que había de suceder de aquellos tamaños golpes con que se amenazaban y la señora del coche y demás criadas suyas, haciendo mil votos y ofrecimiento a todas las imágenes y casas de devoción de España" (I, VIII, 82-83).

En un crescendo narrativo, entre más va narrando y describiendo la batalla, Cervantes logra incrementar la expectativa en su lector. No obstante, llega un momento en el cual detiene lo narrado y confiesa: "Pero está el daño de todo esto que en este punto y término deja pendiente el autor de esta historia esta batalla, disculpándose que no halló más escrito de estas hazañas de don Quijote, de las que deja referidas" (I, VIII, 83). 
Dos observaciones son pertinentes. Primero, es claro que "el daño de todo esto" radica en que el narrador corta de tajo, y en el punto climático, aquello que parecía reivindicar la figura de Don Quijote, es decir la batalla contra Vizcaíno. Con esto, Cervantes logra crear expectación en quien lea o escuche la historia - recordemos que nuestro hábito de lectura individual y en silencio es muy moderno y que data, aproximadamente de siglo XIX-, pues el receptor querrá saber cómo termina este duelo.

Por otro lado, en esta cita, Cervantes introduce el juego de la ficción historiográfica que no trabajará a fondo en éste, sino en el capítulo sucesivo. Esto es, cuando el narrador menciona que el autor de la historia "no halló más escrito de estas hazañas de don Quijote" deja entrever que la obra supuestamente tiene una fuente culta -0 por lo menos escrita - que precede a la hipotética "reescritura" que Cervantes ofrece a su receptor. ${ }^{5}$ Asimismo, este juego se acentúa cuando al narrador le parece imposible que en los anales de la Mancha no exista historia alguna referida a Don Quijote y su batalla con el vizcaíno.

Ya para el capítulo siguiente, que de paso inaugura la segunda parte del Quijote de 1605, Cervantes ahonda en el juego historiográfico ficcional, pues ocupa aquí el viejo motivo del manuscrito perdido y hallado, ${ }^{6}$ así cuenta que, estando en Alcalá de Toledo, compró a un muchacho ciertos cartapacios y papeles viejos que contenían, se supo después, la continuación de la aventura con el vizcaíno.

A la presencia del manuscrito, visto en el Quijote como un juego paródico de dicho motivo en los libros de caballerías, Cervantes añade — como también solía suceder en aquellos textos - el exotismo de ser una obra que originalmente se había escrito en lengua extranjera y de difícil desciframiento, el árabe; además de la inclusión lúdica de un supuesto autor original y primario, un tal "Cide Hamete Benengeli, historiador arábigo" (I, IX, 86). Con respecto a esto, Martín de Riquer señala lo siguiente:

\footnotetext{
${ }^{5}$ El recurso lo vuelve a emplear Cervantes al final de la segunda parte de 1605, una vez que Don Quijote ha sido llevado a la aldea y el narrador menciona: "Pero el autor de esta historia, puesto que con curiosidad y diligencia ha buscado los hechos que de Don Quijote hizo en su tercera salida, no ha podido hallar noticias de ellas a lo menos por escrituras auténticas" (I, LII, 529).

${ }^{6}$ En su artículo "Un truco de la ficción histórica: el manuscrito reencontrado", Carlos García Gual ahonda en la tradición de este motivo, utilizado desde la Antigüedad Clásica. Menciona, así, que este hecho está relacionado tanto con cuestiones de autoridad como de verosimilitud. En el primer caso, en muchas ocasiones, como ocurre en los libros de caballerías, los pretendidos manuscritos se escriben en lenguas exóticas pero de gran autoridad, como el griego, el hebreo y, como sucede en el Quijote, el árabe. Esto debido a que son lenguas de cultura y gran tradición científica. Por otro lado, con respecto a la verosimilitud que debe descansar en lo testimonial, García Gual señala que: "Nada hay más de fiar que el relato en primera persona. No hay mejor recomendación que la afirmación de veracidad de quien ha vivido como actor principal o como testigo inmediato de los sucesos narrados. Ya sea que el narrador se presente como protagonista, o bien como espectador puntual de los hechos memorables que refiere" (47); lo cual es perfectamente atribuible a este pasaje del Quijote.
} 
Todo esto carece de sentido para el lector actual no especializado en la literatura castellana de los siglos XVI y XVII. Los contemporáneos de Cervantes, en cambio, advertían en ello una graciosa parodia del estilo de los libros de caballerías. En efecto, en muchos de ellos es frecuente encontrar que los autores finjan que los traducen de otra lengua o que han hallado el original en condiciones misteriosas. Así, el Ciorolingio de Tracia se presenta como traducido de un original que escribió "Novarco y Promusis en latín"; el Belianis de Grecia se dice: "sacado de lengua griega, en la cual lo escribió el sabio Fristón" (114).

No obstante, lo que resulta interesante - por lo menos para este trabajo- es que dichos cartapacios no sólo contengan la continuación de la "Aventura del vizcaíno" que el narrador había dejado suspensa en el capítulo precedente, sino también, como señala Worden, "thenotion of complementing words with images; it means, a visual depiction of the knight's battle with the Biscayan" ("The first illustrator of Don Quixote; Miguel de Cervantes", 144). Una escena que el narrador describe como sigue:

\begin{abstract}
Estaba en el primero cartapacio pintada muy al natural la batalla de don Quijote con el vizcaíno, puestos en la misma postura que la historia cuenta, levantadas las espadas, el uno cubierto de su rodela, el otro de la almohada, y la mula del vizcaíno tan al vivo, que estaba mostrando ser de alquiler a tiro de ballesta. Tenía a los pies escrito el vizcaíno un título que decía "Don Sancho de Azpetia", que, sin duda, debía de ser su nombre, y a los pies de Rocinante estaba otro que decía "Don Quijote". Estaba Rocinante maravillosamente pintado, tan largo y tendido, tan atenuado y flaco, con tanto espinazo, tan hético confirmado, que mostraba bien al descubierto con cuánta advertencia se le había puesto el nombre de "Rocinante". Junto a él estaba Sancho Panza, que tenía del cabestro a su asno, a los pies del cual estaba otro rétulo que decía "Sancho Zancas", y debía de ser que tenía, a lo que mostraba la pintura, la barriga grande, el talle corto y las zancas largas y por esto se le debió de poner el nombre de "Panza" y de "Zancas", que con estos dos sobrenombres le llama algunas veces la historia. Otras algunas menudencias había que advertir pero todas son de poca importancia (I, IX, 87).
\end{abstract}

Si nos atenemos a la acepción moderna del concepto, ésta es la única descripción ecfrástica que se hace en la primera parte del Quijote, pues, en efecto, se trata del "trazo verbal" de un objeto que — al interior del texto- se reconoce como plástico y tangible, pero que, en realidad, sólo existe por el poder del lenguaje. Y es que, si bien este mismo pasaje ha dado materia para ilustradores posteriores a la obra cervantina, lo cierto es que Cervantes propone un objeto cuya existencia se basa únicamente en el poder de la palabra y la descripción. No obstante, a pesar de parecer un objeto "plástico-literario" netamente acabado y de finísimo trazo, el pasaje no es tan simple y estático como parece, pues podríamos señalar, por lo menos, dos movimientos y dos muestras de ambigüedad; temas en los que me centraré en el siguiente apartado. 


\section{Movimiento y ambigüedad en la écfrasis del "primero cartapacio"}

\subsection{El movimiento de la mirada}

Es cierto: la imagen que contiene el primer cartapacio, en cuanto a re-presentación visual, se entiende y concibe mentalmente como una imagen estática. Sin embargo, habría que decir que, al momento de la lectura, Cervantes propone en realidad un ejercicio visual de una naturaleza cinética plena. Así, comencemos por decir que, en la presentación de la hipotética obra artística, la realidad intratextual re-presentada se expone y percibe a través de la mirada de "alguien", el narrador vuelto personaje.

Lo anterior es: la mirada del narrador, que como personaje compra y manda traducir los cartapacios, es la que nos hace observar y reflexionar acerca la pintura. Incluso, es evidente que su mirada es la que impone las reglas de la espacialidad y distribución en cuanto al cómo debe observarse la obra plástica; así, la mirada del narradorpersonaje es la que guía la mirada del lector/oídor en un acto pleno de movimiento. De esta suerte, el ejercicio que se hace con la imagen que incluye el primero cartapacio se divide en dos planos, el horizontal y el vertical.

La mirada del lector — que se ha vuelto un espectador en segundo grado (o bien un tipo de voyeur), gracias a la mirada del narrador - es horizontal cuando se afirma que, visto de manera general-panorámica, en el cartapacio estaba "muy al natural pintada la batalla..."; posteriormente, es vertical, pues se obliga al lector/oídor a "bajar" la mirada, cuando afirma que "tenía a los pies escrito el vizcaíno un título..."; vuelve a ser horizontal cuando se menciona que "estaba Rocinante maravillosamente pintado". Incluso aquí, el narrador intensifica la idea de la horizontalidad por medio de un juego de adjetivos que caracteriza al caballo, pues éste era "tan largo y tendido"; finalmente, el ejercicio de la mirada al contemplar esta obra vuelve a inclinarse hacia la verticalidad, pues se menciona que "a los pies del [asno] estaba otro rétulo [o rótulo] que decía 'Sancho Zancas"'.

Este análisis se resume a un simple hecho: la mirada guiada, la mirada del lector u oidor - con una perspectiva de segundo grado-, tiene cuatro movimientos principales que quedan claros en un esquema horizontal-vertical-horizontal-vertical. Y aunque quizá esto podría tomarse como una sobreinterpretación, lo cierto es que este juego refleja, precisamente, la naturaleza de la obra misma, que se caracteriza por tener constantes cambios y distintos puntos de vista, ya que podríamos afirmar que, de algún modo, el Quijote es una obra en constante movimiento, y que se narra a través de muchas miradas y muchas voces; no por nada Bajtín la consideró, en su libro dedicado no al escritor español, sino a Dostoievsky, una novela polifónica (Problemas de la poética de Dostoievski, 24).

En este sentido podríamos hablar de una primera función que tiene la écfrasis de la imagen del "primero cartapacio", es decir, la de crear un juego cinético. Sin embargo, aún no hemos tratado el tema de la ambigüedad; y es que, a mi parecer, en la écfrasis, ésta se da, como analizaré a continuación, en la calidad artística de la pretendida obra plástica. 


\section{2. "Estaba pintada artificialmente muy al natural": ambigüedad en la écfrasis del primero cartapacio}

En una primera lectura, cualquier persona que se deleite con este pasaje del Quijote afirmará que la supuesta obra plástica que se presenta aquí es, ante todo, un producto fina y cuidadosamente acabado por su artista, del cual no sabemos ni siquiera el nombre. Esta afirmación se basaría en el siguiente argumento: lexicamente y en más de una ocasión, el narrador describe las imágenes como algo muy bien trabajado y que, en ningún momento, son infieles a la realidad, que él entiende como naturalidad.

Así, las palabras que inauguran el ejercicio ecfrástico son éstas: "estaba en el primero cartapacio pintada muy al natural la batalla de Don Quijote con el vizcaíno". Con el simple sintagma muy natural, el narrador deja entendido que la re-presentación ni es exagerada, ni es pormenorizada, sino supuestamente fiel a la naturaleza y a la realidad. En suma, es mimética y es por ello que causa asombro. Un hecho mimético que casi podría acercar la obra plástica a los terrenos de la maravilla; y esto lo sabe el narrador (¿o Cervantes?) pues lúdicamente menciona que "estaba Rocinante maravillosamente pintado".

La fidelidad a la realidad y a la naturaleza, así como lo asombroso en el trazo del artista que elaboró la pintura, se observan de nueva cuenta cuando se habla de la mula del vizcaíno, puesto que estaba representada "tan al vivo, que estaba mostrando ser de alquiler a tiro de ballesta", lo cual quiere decir que la representación era tan fiel a su modelo y detallada que, desde lejos, podría observarse que se trataba no de un fino animal, sino de una bestia de carga, acostumbrada a los trabajos rudos.

No obstante, la caracterización más asombrosa —y también la más jocosa - llega cuando se habla de Rocinante, pues el pintor lo ha representado sumamente fiel a cómo se presenta a la realidad intraliteraria; es decir, se trata de un caballo "tan atenuado y tan flaco, con tanto espinazo, tan hético confirmado, que mostraba bien al descubierto con cuánta advertencia se le había puesto el nombre de 'Rocinante'". Luego, la caracterización del personaje no sólo se da gracias al nombre y su carga semántica, ${ }^{7}$ sino también a una serie de adjetivaciones que del caballo se leen en la descripción de la pintura y que lo retratan, en efecto, como una bestia tísica que más inspira compasión e hilaridad, que temor.

A todo esto, entonces, habría que decir que, por lo menos, las figuras de los animales han sido representadas y caracterizadas de manera asombrosa por el artista que ilustra el primero cartapacio. Empero, ¿sucede lo mismo con las figuras humanas? Al parecer, no. Veamos.

La primera figura humana de la que se habla en la écfrasis con mayores caracterizaciones es la del adversario de Don Quijote. En realidad, no se trata de una descripción física, pero sí de una caracterización de personaje, ya que "tenía a los pies

\footnotetext{
${ }^{7}$ Rocín significa, según el DRAE: "Caballo de mala traza, basto y de poca alzada"; o bien "Caballo de trabajo, a distinción del de regalo" (s.v.).
} 
el vizcaíno un título que decía 'Don Sancho de Azpetia"'. Al decir esto, el narrador le da una mayor identidad al enemigo, por el simple hecho de otorgarle un nombre, mismo que no se repetirá a lo largo de la obra y que, por ende, sólo lo sabemos gracias a la écfrasis de esta imagen. No obstante, caben dos preguntas: ¿por qué emplear el nombre de pila del fiel acompañante de Don Quijote también para el adversario? ¿Acaso habría aquí un juego de ambigüedad que Cervantes deseó emplear para disturbar al lector, pues en la representación habría, entonces, dos Sanchos; uno amigo y otro enemigo? Lo cierto es que, en efecto, al saber el nombre del vizcaíno el lector/ oidor tiene a dos personajes que, dentro de una misma escena, poseen el mismo nombre de pila.

Por otro lado, apropósito del título que tiene el vizcaíno y que le dota de un nombre, el narrador menciona que "a los pies de Rocinante estaba otro que decía 'Don Quijote". Por el orden sintáctico, se entiende que la palabra otro se refiere a "otro título"; y éste es el que da el nombre del protagonista. Empero, hay que mencionar que la inscripción se encuentra a los pies del caballo, pero no a los pies de Don Quijote, a quien - si bien asumimos montado en el equino-, curiosamente, el narrador no describe. El caballero manchego es, entonces, el gran ausente en la descripción ecfrástica, ya que no podemos encontrar ningún elemento que devele su caracterización en la imagen, fuera de la alusión que a él se hace al comenzar el ejercicio, cuando se menciona: "el uno [estaba] cubierto de su rodela".

Don Quijote, luego, se vuelve para el lector/oidor, el inasible, el indescriptible, el invisible, la imagen que traviesamente se nos escapa. ¿Qué habrá querido decir con esto Cervantes? ¿A caso que su personaje no era de una sola pieza para poder presentarlo a manera de una re-presentación? ¿O bien que la naturaleza de Don Quijote era complicada para representarla de manera doblemente mediada, es decir, primero por la palabra y después por la supuesta imagen? Igualmente, no hay respuesta a estas preguntas, pues lo único que tenemos a ciencia cierta es la obra en sí misma y esta caracterización más bien ausente. Caso contrario sucede con Sancho, a quien la écfrasis describe de esta manera:

\footnotetext{
Junto [a Rocinante] estaba Sancho Panza, que tenía del cabestro a su asno, a los pies del cual estaba otro rétulo que decía "Sancho Zancas", y debía de ser que tenía, a lo que mostraba la pintura, la barriga grande, el talle corto y las zancas largas y por esto se le debió de poner el nombre de "Panza" y de "Zancas", que con estos dos sobrenombres le llama algunas veces la historia (I, IX, 87).
}

Como se observa a simple vista, de entre las caracterizaciones a los personajes, ésta es la más larga y quizá también la más ambigua; primero porque el título que nombra al personaje no aparece precisamente a los pies de Sancho, sino a los pies del rucio; mientras que, por otro lado, la caracterización física que se da del acompañante de don Quijote es muy contraria a la que tiene el personaje en el imaginario colectivo. Es decir, la re-presentación icónica descrita por medio de la écfrasis es la de un hombre 
regordete de caja toráxica corta, pero de piernas largas, no de baja estatura como lo conocemos por tradición. Por eso, según dice el texto, el artista puso en el título el nombre de Sáncho Zancas, pues, según el narrador, "con estos dos sobrenombres le llama algunas veces la historia". Empero, como bien señala Worden (149), esto no es así, pues después de este pasaje, en todo el Quijote, a Sancho no se le vuelve a nombrar de esta manera. Por lo tanto, ante estas observaciones ¿qué debemos pensar de la supuesta re-presentación plástica de la batalla de don Quijote contra el vizcaíno y la descripción del primero cartapacio? Me parece indicado rescatar dos ideas: primeramente digamos que, como ya lo ha señalado Worden: "the artwork within the work of art that is Don Quixiote seems to be reminding us, yet again, that things are not always what they seem to be" (147). Y es que, si bien es cierto que, en un principio, el supuesto objeto plástico parece ser una obra cuidadosamente elaborada; también es verdad que la obra per se cuenta con algunos detalles que parecerían ser un error del artista que elaboró la imagen; entre ellos, evidentemente, el nombre que se le da a Sancho y su caracterización. En este sentido, Worden ha dicho:

The use of ekphrasis in this episode helps Cervantes make clear, as he does in a number of ways through the novel, the potential jarring disparities between ser (being) and parecer (seeming). At first glance, the description of the illustration would appear to suggest that it is the work of an accomplished artist [...] nevertheless, the reader may come to the conclusion that the names included in the illustration (Don Sancho de Azpetia, Don Quijote and Sancho Zancas) could quite possibly be an indication of not clarity, but rather an artistic ineptness $(146-147,148)$.

Aunque quizá la idea de ineptitud del supuesto artista sea desmedida, lo que hay que rescatar en esta cita es, precisamente, la idea de no claridad (not clarity), pues esta característica es lo que provoca ambigüedad en algunos elementos de este pasaje, como sucede con la caracterización de Sancho. Yendo aún más lejos, la presencia de la écfrasis en el Quijote es ambigua en sí misma, pues no sabemos si con esto Cervantes hacía nuevamente una parodia de los viejos recursos utilizados, no sólo en los libros de caballerías, sino en gran parte de la épica clásica y medieval, que, al igual que este pasaje, dejan en suspenso la narración para hacer una gran digresión, en la que incluso hay espacio para describir un objeto artístico. ${ }^{8}$

Como quiera que esto sea, aún falta mencionar que existe un último elemento en esta écfrasis que, indirecta y paradójicamente, dota a la pintura de una gran y última movilidad, aunque en principio se haya concebido como un objeto absolutamente estático: me refiero a la enárgeia, en cuyo concepto y aplicación a la imagen del primero cartapacio me enfocaré en el siguiente y último apartado.

\footnotetext{
${ }^{8}$ La écfrasis de la Ilíada que he señalado al principio de este trabajo se presenta justo antes de comenzar una batalla; mientras que la écfrasis de la tienda de Alejandro, en el Libro de Alexandre, se presenta también a manera de digresión, justo cuando la obra está por concluir; de ahí su importancia retórica ya que, al contar de nuevo las hazañas de Alejandro, funge como una peroratio.
} 


\section{3. "Y el primero que fue a descargar el golpe, fue el colérico vizcaíno"; enárgeia y movimiento}

Uno de los conceptos ampliamente relacionados con la écfrasis es el de enárgeia - en latín evidentia - que puede ser definida como: "the power of language to create a vivid prescence" (Lunde, 2004: 52). A su vez, la enárgeia está relacionada con la idea de movimiento que, paradójicamente, la descripción de una imagen estática pueda sugerir.

Entre las Descripciones de cuadros que Filóstrato hace en el siglo IV, se encuentra un sinnúmero de ejemplos de obras pictóricas que sólo existen por el poder del lenguaje, la doble representación y la descripción. Asimismo, estas descripciones poseen una considerable carga cinética, a pesar de tratarse de supuestas imágenes estáticas. De esta suerte, en las Imágenes de Filóstrato el Viejo, cuando describe el sexto cuadro -una pieza que retrata un grupo de amorcillos en un locus amoenus - , se menciona lo siguiente:

¡Mira! Los Amores están recolectando manzanas. No te extrañe que sean tantos. Pues estos niños, hijos de las ninfas, gobiernan a todo el género humano: son muchos porque muchos son los objetos de amor de los hombres [...]. No hablemos de estos que bailan o de los otros que corretean de un lado a otro; o bien, de estos otros que duermen o que se divierten zampando las manzanas (Descripciones de cuadros, 232-233).

Como se lee, la imagen que se describe, lejos de parecer una pintura estática, cuenta, por el contrario, con gran movimiento. Y esto se logra gracias al uso exclusivo del lenguaje, es decir, al uso de verbos que, semánticamente, implican movilidad; además de estar conjugados en tiempos y modos que dotan, precisamente, de enárgeia a la supuesta representación.

Los ejemplos podrían ser muchos y no exclusivos de la obra de Filóstrato. Recordemos que la práctica ecfrástica en la Edad Media contó también con descripciones poéticas plenas de movimiento. Así, cuando el escritor del ya citado Libro de Alexandre describe la representación de los meses en la tienda de Alejandro, se basa también en el uso verbal para crear una imagen alegórica que debería ser estática y que, empero, simplemente no lo es. De esta manera, al describir el primer mes del calendario, menciona:

Estava don Janero a dos partes catando cercado de çecinas, çepas acarreando; tenié gruesas gallinas, estávalas assando, estaba de la percha longaniças tirando. (c. 2555, las cursivas son mías) 
Con esta tradición a cuestas, de alguna manera Cervantes hace también uso de esta técnica. Incluso, podríamos decir que ahonda en el uso literario, pues de cierta forma lo engarza perfectamente tanto con el hecho de haber dejado la narración suspendida, como también con el motivo del manuscrito hallado. Explico esto con detalle.

La primera parte del Quijote de 1605 termina, como ya hemos visto, con la batalla entre el vizcaíno y el caballero andante presentada como una acción congelada, pero marcando una escena precisa, la de las espadas de los contrincantes puestas en alto. Así: "Venía, pues, como se ha dicho, Don Quijote contra el cauto vizcaíno, y el vizcaíno le aguardaba asimismo levantada la espada y aforrado con su almohada" (I, VIII, 83).

Posteriormente, después del hallazgo de los cartapacios, el narrador-personaje se da cuenta de que la imagen que ilustra aquel manuscrito contiene esta misma escena, pues los contrincantes estaban "puestos en la misma postura que la historia cuenta, levantadas las espadas, el uno cubierto de su rodela, el otro de la almohada" (I, IX, 87). Después, como ya vimos, el narrador se dedica a entrar plenamente en la écfrasis; y al terminar este ejercicio, realiza una breve digresión en donde discute tres temas principales: 1) la historia de Don Quijote ha sido originalmente escrita por un árabe, lo cual puede considerarse como la única tacha de la misma; 2) los historiadores deben ser fieles a la verdad (y esto Cervantes lo incluye evidentemente como algo lúdico y jocoso, pues Cide Hamete constituye su gran juego de ficción-verosimilitud), y, finalmente, 3) el narrador se cura en salud, pues menciona que si el lector encuentra algunos fallos en la historia no es su culpa, sino del autor árabe. Así pues, retoma lo que había dejado inconcluso en el capítulo VIII de la siguiente manera:

En fin, su segunda parte, siguiendo la traducción, comenzaba de la siguiente manera: puestas en alto las cortadoras espadas de los dos valerosos y enojados combatientes, no parecía sino que estaban amenazando al cielo, a la tierra y al abismo: tal era el denuedo y el continente que tenían. Y el primero que fue a descargar el golpe fue el colérico vizcaíno; el cual fue dado con tanta fuerza y tanta furia, que al no volvérsele la espada en el camino, aquel golpe fuera bastante para dar fin a su rigurosa contienda (88, las negritas son mías).

Es cierto que, para el momento en el que el lector ha llegado a esta cita, el ejercicio de la écfrasis ha terminado. No obstante, como se ha visto líneas arriba, debido a la semejanza de vocablos (sobre todo la insistencia de mantener "las espadas en alto") la descripción experimenta cierto tipo de enárgeia, pues de un estado absolutamente estático, la escena retoma vida, movimiento y fuerza; y esta vez para seguir el cauce de la narración.

Aunque es cierto que no se trata de una enárgeia paradigmática relacionada en sentido absoluto con la écfrasis — como en el caso de la obra de Filóstrato-, es debido reconocer en Cervantes el uso magistral del lenguaje, pues al igual que los ejemplos ya citados, la imagen congelada adquiere cierto movimiento por el uso de 
ciertos vocablos. Es decir, el paso de la estaticidad al movimiento se marca perfectamente con palabras y sintagmas.

De esta suerte: "puestas en alto las cortadoras espadas", o bien "no parecía sino que estaban amenazando al cielo" son ejemplos, ambos, de la estaticidad en la escena. No obstante y en contraste, se menciona: "Y el que fue descargar primero el golpe fue el colérico vizcaíno; el cual fue dado con tanta fuerza y tanta furia...", etcétera. El primer término que indica una idea de movimiento y descongelamiento de la escena es el verbo descargar, pues implica mover algo hacia abajo; y este movimiento se da de determinada forma, es decir coléricamente, con "tanta fuerza y tanta furia", lo que acentúa la potencia que retoma el movimiento y, por lo tanto, la enárgeia que, en este justo momento, da paso a la continuación de la narración y devenir de la narración. Con esto Cervantes logra unir lo que parecía roto, lo que parecía una imagen y su propio texto. Es entonces que la narración continúa.

La écfrasis de la imagen que contiene "el primero cartapacio" en el capítulo IX de $E l$ ingenioso hidalgo don Quijote de la Mancha debe tomarse como un juego jocoso lleno de ambigüedades que Cervantes ha planteado a su lector. En primer lugar, hay que decir que, con este ejercicio, el autor de la obra aparentemente sigue los cánones no sólo de los libros de caballería, sino de toda una tradición épica en donde los héroes se relacionan con descripciones de objetos artísticos que, o bien son parte de sus armaduras, o bien - como es el caso - cuentan hazañas importantes de sus vidas. En este sentido, la écfrasis del primero cartapacio también está ligada a los conceptos de gloria y fama que Don Quijote, en tanto héroe y caballero extemporáneo, tanto anhela. Empero, es claro que no debemos observar las cosas de manera absolutamente seria, pues Cervantes propone con esto, más que una parodia, un juego con su lector o escucha.

Este juego, que es la écfrasis misma, se halla pleno de movimiento, a pesar de tratarse de la descripción de un objeto estático; y es que, en este sentido, la écfrasis del "primero cartapacio" se debe observar como un objeto que posee algunos de los elementos que caracterizan a la obra en su totalidad; en primer lugar, el juego de la movilidad, el juego del engaño, el juego de la ficción-verosimilitud y, finalmente, la historia que cuenta una mirada ajena y nunca absoluta ni agotable, como inagotable es la manera en que esta obra, sin duda, se puede leer.

\section{Obras citadas}

Aftonio, Teón, Hermógenes. 1991. Ejercicios de retórica. Trad. Ma. Dolores ReChe Martínez. Madrid: Gredos, 1991.

BAJTín, Mijaíl. 1979. Problemas de la poética de Dostoievski. Trad. Tatiana BuBNOVA. México: FCE. 
CAmpos García-Rojas, Axayácatl. 2007. "Historia y amor ex arte en los libros de caballerías hispánicos: Espejo de príncipes y caballeros". "Los bienes, si no son comunicados, no son bienes". X Jornadas Medievales. Eds. Axayácatl CAmpos García-Rojas, Mariana Masera y María Teresa Miaja. México: El Colegio de México / unam. Pp. 71-86.

Cervantes SaAvedra, Miguel de. 2004. El ingenioso hidalgo don Quijote de la Mancha. Ed. Fransisco Rico. Madrid: Real Academia Española / Alfaguara.

CurTiUs, Ernest Robert. 1995. Literatura europea y Edad Media latina. Trad. Margit FrenK y Antonio Alatorre. México: FCE.

Filóstrato. 1996. Heroico Gimnástico y Descripciones de cuadros. Introd. Carles Miralles. Trad. Francesca Mestre. Madrid: Gredos.

GARCÍA GuAL, Carlos. 1996. "Un truco de la ficción histórica: el manuscrito reencontrado". Anuario de la Sociedad de Literatura Española General y Comparada, núm. 10. Pp. 47-60.

HeFFERnAN, James A. W. 1993. Museum of words. The poetics of Ekphrasis from Homer to Ashbery. Chicago: The University of Chicago Press.

Homero. 2008. Ilíada. Trad. Emilio CREsPo GüEMES. Madrid: Gredos.

Libro de Alexandre. 2003. Ed. Jesús CAÑAs Murillo. Madrid: Cátedra.

LOZANO-RENIBLAS, Isabel. 2005. "La écfrasis de los ejércitos o los límites de la enárgeia". Monteagudo: Revista de Literatura Española, Hispanoamericana y Teoría de la Literatura, núm. 10. Pp. 29-38.

LUNDE, Ingunn. 2004. "Rhetorical enargeia linguistic pragmatics. On speech-reporting strategies in East Slavic medieval hagiography and homiletics". Journal of Historical Pragmatics, núm. 5, vol. 1. Pp. 49-80.

Real ACADEmia EsPañola: Banco de datos (Corde). Corpus diacrónico del español. Web. 25 de noviembre de 2009. <http://www.rae.es.>.

RiQuer, Martín de. 2003. Para leer a Cervantes. Barcelona: Acantilado.

SPITZER, Leo. 1955. "The ode on a Grecian Urn, or Content vs Metagrammar". Comparative Literature, vol. 7, núm. 3. Verano. Pp. 203-225.

WordEN, William. 2005. "The first illustrator of Don Quixote; Miguel de Cervantes". Ekphrasis in the Age of Cervantes. Ed. Frederick A. DE ARMAS. Lewisburg: Bucknell University Press. Pp. 144-155. 